\title{
Assessing the Cadmium Effects on the Benthic Foraminifer Ammonia cf. parkinsoniana: An Acute Toxicity Test
}

\author{
María Teresa Losada Ros ${ }^{1}$, Eqbal Al-Enezi ${ }^{2}$, Erica Cesarini ${ }^{3}$, Barbara Canonico ${ }^{3} \oplus{ }^{\circ}$, Carla Bucci ${ }^{4}$, \\ Maria Virgínia Alves Martins ${ }^{5,6}(\mathbb{D})$, Stefano Papa ${ }^{3}(\mathbb{D})$ and Fabrizio Frontalini ${ }^{4, *(D)}$ \\ 1 Ocean Science Consulting Ltd., Dunbar EH42 1RR, East Lothian, UK; t1@osc.co.uk \\ Kuwait Institute for Scientific Research, Safat 13109, Kuwait; eenezi@kisr.edu.kw \\ 3 Department of Biomolecular Sciences, Urbino University, 61029 Urbino, Italy; erica.cesarini@uniurb.it (E.C.); \\ barbara.canonico@uniurb.it (B.C.); stefano.papa@uniurb.it (S.P.) \\ 4 Department of Pure and Applied Sciences, Urbino University, 61029 Urbino, Italy; carla.bucci@uniurb.it \\ 5 Departamento de Estratigrafia e Paleontologia, Universidade do Estado do Rio de Janeiro, Rio de Janeiro \\ 20550-013, Brazil; virginia.martins@ua.pt \\ 6 Departamento de Geociências, Universidade de Aveiro, 3810-193 Aveiro, Portugal \\ * Correspondence: fabrizio.frontalini@uniurb.it; Tel.: +39-3928457666
}

Received: 11 March 2020; Accepted: 30 March 2020; Published: 2 April 2020

\begin{abstract}
Heavy metals are one of the most hazardous pollutants in marine environments because of their bioaccumulation and biomagnification capabilities. Among them, cadmium $(\mathrm{Cd})$ has been considered as one of the most dangerous for marine organisms. Here we incubated Ammonia cf. parkinsoniana specimens, a benthic foraminiferal taxon used in previous experiments, for up to $48 \mathrm{~h}$ in natural seawater with different concentrations of $\mathrm{Cd}$ to unravel the physiological change. We document a reduced pseudopodial activity of the Cd-treated specimens at concentrations $>10-100 \mathrm{ppb}$ in comparison with the control specimens. Moreover, confocal images of Cd-treated specimens using Nile Red as a fluorescent probe reveal an enhanced intracellular neutral lipid accumulation in the form of lipid droplets at $6 \mathrm{~h}$ and $12 \mathrm{~h}$. This bioassay experiment allows for the direct evaluation of $\mathrm{Cd}$-dose to $A$. cf. parkinsoniana-response relationships under laboratory controlled conditions and provides complementary information to field observations as well as to water quality guidelines and thresholds.
\end{abstract}

Keywords: cadmium; benthic foraminifera; ecotoxicology; confocal images

\section{Introduction}

Marine environments have been progressively threatened and impacted by human activities in the last centuries [1]. Since most of the effluents ultimately discharge in marine coastal and transitional environments, such sensitive ecosystems are commonly the most affected.

Among all pollutants, the group of elements known as heavy metals is regarded as the most threatening for marine ecosystems [2]. Heavy metals are naturally present in the environment, and organisms can even benefit from them, if at low concentrations, as they play important roles in cellular metabolism and enzymatic activity (e.g., [3]). At higher concentrations, they may however lead to chronic or acute effects on biota $[4,5]$. Heavy metals do not degrade, instead, they bioaccumulate and biomagnify through the food web [6]. Among them $\mathrm{Hg}, \mathrm{Pb}, \mathrm{Cr}$ and $\mathrm{Cd}$ are considered particularly toxic for marine organisms [4]. In fact, they can enter into the organisms and induce mutagenesis, loss of enzymatic activity, the production of reactive oxygen species (ROS), ultrastructural damage and even apoptosis [6,7]. 
Cadmium is released from natural and anthropogenic sources, the latter mainly being from smelters and industrial activities. This element is reported to be a non-biological essential rather persistent pollutant, the effects of which vary from teratogenic to carcinogenic, and likely also mutagenic [8]. Cadmium uses a Trojan horse strategy by mimicking essential metals for the metabolism. It is therefore capable of accumulating in the milk and tissues such as fatty tissue [9-11] and muscle [9]. In mammals, malfunctions such as increased lipid peroxidation in liver and kidneys [11], bone fracture, cancer [12], hypertension [13], airway disease, emphysema and immunosuppression [14] were found to be related to $\mathrm{Cd}$ exposure. In cell lines, it was suggested that the exposure to high concentrations of $\mathrm{Cd}$ leads to several damages, such as disruption of the cytoskeleton, increase of the lysosomal activity [15], disruption of cell membranes, alteration of gene expression and production of ROS [14,16].

In light of this, $\mathrm{Cd}$ is accurately monitored in natural environments. The average background/reference concentrations of Cd vary from 0.07 and $1.1 \mathrm{mg} / \mathrm{kg}(\mathrm{ppm})$ in surface soil, $5.0-20 \mathrm{ng} / \mathrm{L}(\mathrm{ppt}$ ) in seawater, from 0.03 to $1.0 \mathrm{mg} / \mathrm{kg}$ (ppm) in marine sediments ([17] and reference therein). On the basis of acute toxicity tests, it has been revealed that ambient $\mathrm{Cd}$ water concentrations exceeding $10 \mathrm{ppb}$ lead to toxic effects (e.g., mortality, reduced growth), though marine organisms are considered more tolerant than freshwater ones [8]. Sublethal effects are reported to occur at $0.5-10 \mathrm{ppb}$ concentrations [8].

Benthic foraminifera, marine protozoa enclosed in a shell, have been widely used as proxies for the environmental assessment of marine ecosystems (e.g., [18]). Natural ecosystems are, however, rarely affected by a single pollutant but, more frequently, by a mixture of them. Under this circumstance, the effective evaluation of the effect of a single pollutant is hampered. In light of this, laboratory experiments allow for a reliable quantification of the effect of a single pollutant under controlled conditions and add reliability to field-based observations $[19,20]$. Culture and mesocosms experiments have been applied to study the effects induced by different heavy metals at species' and at foraminiferal assemblages' level, respectively. Despite the simplicity and versatility of these experiments, very few studies have been published on the noxious effect that a single pollutant might trigger in the physiology of the foraminiferal cell in terms of tolerance, growth, reproduction and/or survival (e.g., $[4,19,21-26])$, and even more limited is the number of publications on ultrastructural and physiological changes induced by exposure to pollutants (e.g., [20] for review) or to Cd exposure [4,24].

In this contribution, we aim therefore to evaluate the effects of short-term exposure to different concentrations of $\mathrm{Cd}$ of the benthic foraminiferal species Ammonia cf. parkinsoniana. Here we document, in this in vivo experiment, the possible variations of pseudopodial activity and the intracellular lipid accumulation on Cd-treated specimens.

\section{Materials and Methods}

The sediment sample was collected in a coastal site $\left(29^{\circ} 23.694 \mathrm{~N}-47^{\circ} 54.612 \mathrm{E}\right.$, at a water depth of $5.2 \mathrm{~m}$ ) off Sulaibikhat Bay within Kuwait Bay (Kuwait, Arabian Gulf) on January 2018. At the collection site, temperature, $\mathrm{pH}$, salinity, Eh and dissolved oxygen were measured in vertical profile with a multiparametric probe. The physicochemical parameters of bottom water are the following temperature $13.7^{\circ} \mathrm{C}$, salinity $42.2, \mathrm{pH} 8.56$, the Chlorophyll a $7.4 \mu \mathrm{g} / \mathrm{L}$, and dissolved oxygen $96.8 \%$ and $7.72 \mathrm{mg} / \mathrm{L}$. A large volume of sediment was collected with a grab and only the uppermost layers $(2 \mathrm{~cm})$ were retained. This fraction was kept in insulated boxes covered by natural seawater (NSW), kept near ambient temperature and delivered to the micropaleontological lab of Urbino University (Italy). At the same laboratory, artificial sea water (ASW) was prepared, stored in darkness, aerated and mixed under in situ temperature. ASW was prepared with the same salinity value of NSW to avoid any stress on foraminifera. Sediment was then washed with ASW and sieved through a sieve of $125 \mu \mathrm{m}$. The resulting sediment bearing foraminiferal fraction was treated with CellHunt Blue (CHB) CMHC (4-Chloromethyl-7-hydroxycoumarin) of Setareh Biotech (US). The CHB is a fluorogenic probe that passes through the cell membrane, and once within the cell, it is transformed into cell membrane-impermeant reaction products. This probe with blue excitation/emission spectra $(353 / 466 \mathrm{~nm}$ 
maxima) has been used to check the viability of benthic foraminifera [27]. Other fluorescence-based methods have been used to assess the viability of specimens, as the widely used CellTracker Green. As specimens were intended to be treated with the fluorescent dye Nile Red (NR), the CHB was selected to avoid any kind of interference and overlap. The sediment was incubated for $24 \mathrm{~h}$ with $\mathrm{CHB}$ and labeled foraminifera were hand-picked with a fine brush under the light of an epifluorescence stereomicroscope (Stereo Discovery V8, Zeiss) equipped with a light fluorescent source (DAPI LED 68) working at an emission of $377 \pm 28 \mathrm{~nm}$ and at an excitation of $464 \pm 100 \mathrm{~nm}$. Picked specimens of $A$. cf. parkinsoniana were placed on Petri dishes covered with NSW. This taxon was chosen to have a comparison with previous published papers $[25,26,28]$. In fact, this taxon has been selected, in previous studies, to test the effects of lead [25], mercury [26] and a set of nanoparticles (titanium dioxide, polystyrene and silicon dioxide) [28]. The taxon is very similar to Ammonia aff. beccarii of [29] (plate 8, n. 8) and Ammonia elegans of [30] (plate 9, n. 3-5).

A total of six Cd-NSW mixtures reflecting different concentrations of $\mathrm{Cd}$ including a control were prepared (Figure 1). Cadmium chloride $\left(\mathrm{CdCl}_{2}\right)$ of $98 \%$ purity was used for the experiments (Santa Cruz Biotechnology). The final experimental concentrations were 1 ppb, 10 ppb, 100 ppb, 1 ppm, $10 \mathrm{ppm}$, and the control. The selection of these concentrations was based on a background level of Cd-uncontaminated coastal seawater and marine sediment (as well as previous toxicological studies (acute toxicity and sublethal effect) (i.e., [17] and reference therein).

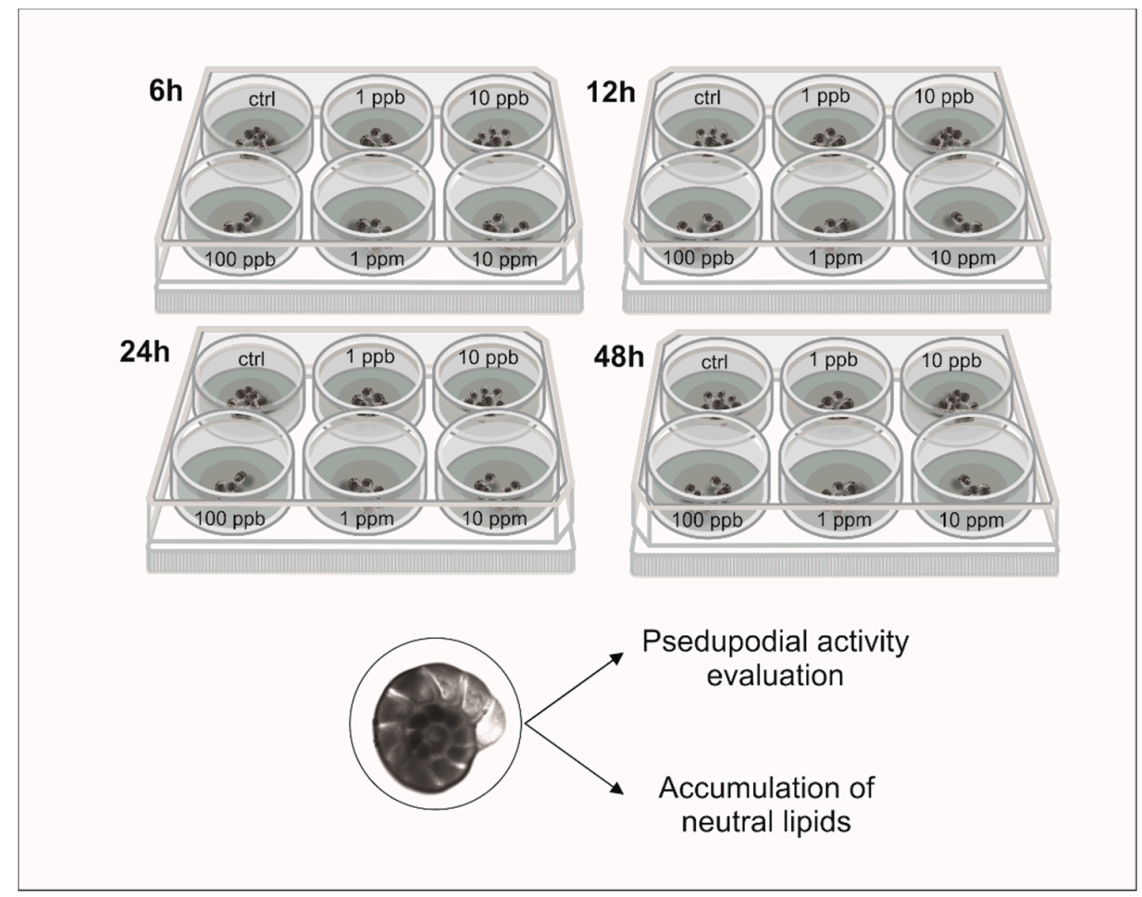

Figure 1. Schematic design of the experiment. The multiwell culture plate denotes the time $(6 \mathrm{~h}, 12 \mathrm{~h}$, $24 \mathrm{~h}$ and $48 \mathrm{~h}$ ), whereas the wells represent the Cd concentrations (control, 1 ppb, $10 \mathrm{ppb}, 100 \mathrm{ppb}$, $1 \mathrm{ppm}$ and $10 \mathrm{ppm}$ ). Living specimens of $A$. cf. parkinsoniana were placed in each well and analyzed at a pre-established time interval for pseudopodial activity and lipid content.

A total of 600 living individuals of $A$. cf. parkinsoniana were transferred to six well tissue culture plates UltraCruz ${ }^{\circledR}$ and covered with the $\mathrm{CdCl}_{2}-\mathrm{NSW}$ mixtures (Figure 1). At least twenty individuals were placed in each well. Plates were then left in a controlled environment, in darkness and at room temperature. The viability of the individuals was rechecked at the start of the experiment (time 0 ) and at $6 \mathrm{~h}, 12 \mathrm{~h}, 24 \mathrm{~h}$ and $48 \mathrm{~h}$. The method chosen for recognizing the status of the specimens was the direct observation of the pseudopodial activities through an inverted microscope (Leica DMI 6000 CS, Leica Microsystems, Heidelberg, Germany). Only specimens that presented a clear stream of pseudopodia 
were counted as living, all the others were counted as non-living individuals. However, it would be stressed, as suggested by [24], that the lack of pseudopodial activity cannot be directly related to the mortality of the foraminiferal specimens, in fact, the cytoplasm can be retracted within the test under adverse conditions. Images of the specimens were taken with a Nikon Eclipse TS100 and a Nikon Digital Sight DS-Fi1 camera.

From the total number of specimens, 168 individuals of $A$. cf. parkinsoniana were labeled with NR then scanned with confocal laser scanning microscopy (CLSM). The NR, a fluorescence-based method to study the lipids within the cell, is a phenoxazine dye that can be used on living and fixed cells to localize and quantify neutral and polar lipids [31,32]. The absorption and fluorescence properties of NR are known to be sensitive to environmental factors such as polarity. Polar lipids (i.e., phospholipids), which are mostly present in membranes, fluoresce red (emission >590 nm) whereas lipids fluoresce yellow (570-590 nm) [33,34]. The specimens were treated, observed and imaged following the methodology of [26,28]. The NR mean fluorescence intensity (MFI) analyses were performed using ImageJ software (NIH, Bethesda, MD, USA) by imaging specimens at the same level of magnification, and determining the MFI of all the selected pixels. Subsequently, yellow MFI values were converted to arbitrary units (A.U.) setting the first image of the control specimens at 100. The fluorescence emission of lipids droplets (LD) was calculated in the yellow channel using at least 5 specimens for each condition. The Student's $t$-test was used to check for significant differences of pseudopodial activity and MFI values among experimental conditions (i.e., concentrations) grouped for time of exposure.

\section{Results}

\subsection{Pseudopodial Activity}

Cadmium-treated and control specimens were checked for the pseudopodial activity. To be considered as viable, individuals had to show clear movements in their pseudopodia. At the beginning of the experiment, all specimens were healthy and showed extensive pseudopodial activity. On the basis of our experiment, a general tendency to decrease in the number of individuals showing pseudopodial activities, both time- and concentration-wise, was observed (Figure 1 and Table S1). Specimens exposed to the lowest concentrations of $\mathrm{Cd}(1 \mathrm{ppb})$ showed the most stable percentages of pseudopodial activity through the duration of the experiment, the only marked lowering of percentages was observed after $48 \mathrm{~h}$ exposure at $1 \mathrm{ppb}$ (Figure 2).

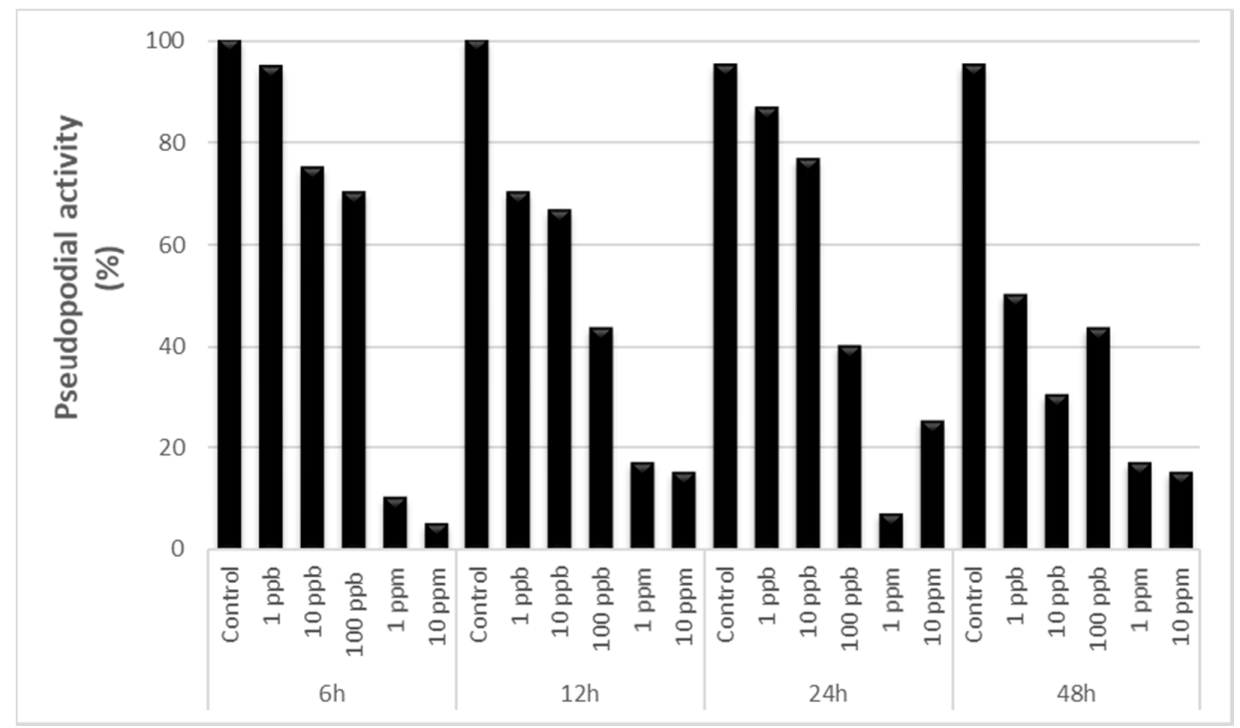

Figure 2. Histograms of percentages of $A$. cf. parkinsoniana specimens exhibiting pseudopodial activity for the treatments (control and five Cd-concentrations) and over time (6 h, $12 \mathrm{~h}, 24 \mathrm{~h}$ and $48 \mathrm{~h})$. 
Specimens treated with the highest concentrations of $\mathrm{Cd}$, namely $1 \mathrm{ppm}$ and $10 \mathrm{ppm}$, exhibited a substantial decrease in pseudopodial activity. The percentages of specimens with pseudopodial activity at 1 ppm and 10 ppm conditions were quite stable with a marked reduction occurring after $6 \mathrm{~h}$ treatment. The lowest values of pseudopodial activity were documented at $10 \mathrm{ppm}$ after $6 \mathrm{~h}$ exposure (4.8\%) and at 1 ppm after $24 \mathrm{~h}$ exposure (6.7\%) (Figure 2). All treatments except for $1 \mathrm{ppb}$ were significantly different $(p<0.05)$ from the control.

\subsection{Laser Confocal Scan Microscopy}

Cadmium treated specimens of $A$. cf. parkinsoniana were labeled with NR and analyzed through the CLSM in order to document the lipidic changes in the cell during the experiment. In control specimens (no Cd exposure), the lipids within the cell showed a regular distribution in all the analyzed specimens along the experiment with low yellow fluorescence levels (Figure 3).

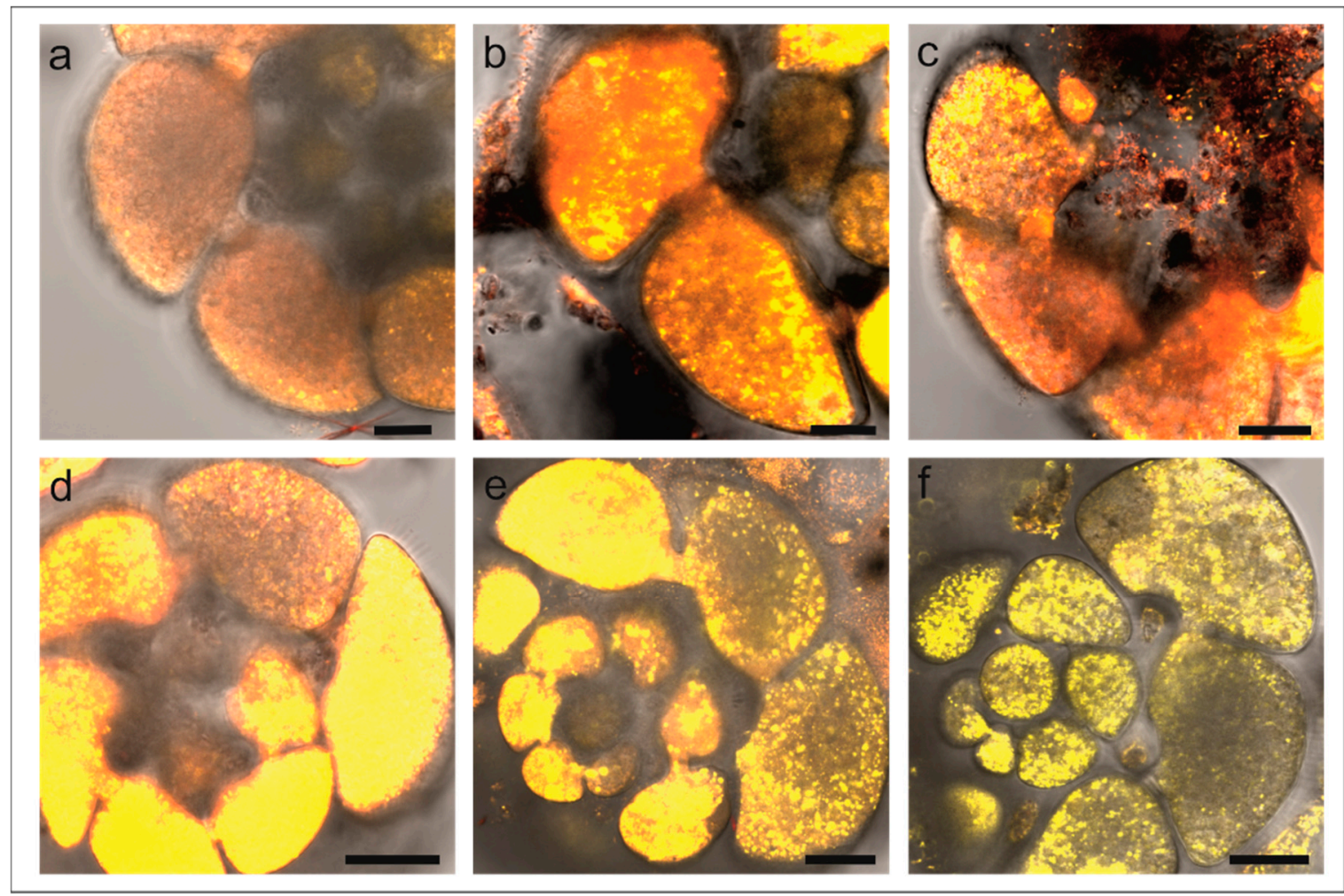

Figure 3. Effect of $\mathrm{Cd}$ exposure on lipid distribution of $A$. cf. parkinsoniana labeled with Nile Red (NR). Epifluorescence micrographs of single optical sections showing overlay of NR yellow and red fluorescence at $6 \mathrm{~h}$ : (a) Control; (b) 1 ppb; (c) 10 ppb; (d) 100 ppb; (e) 1 ppm; (f) 10 ppm. Scale bars: $25 \mu \mathrm{m}$.

Conversely, the specimens treated with Cd exhibited an enhanced yellow fluorescence (Figure 3). These results were confirmed by NR MFI quantification, where a concentration-dependent yellow fluorescence increase after $6 \mathrm{~h}$ and $12 \mathrm{~h}$ exposure in the specimens treated with $\mathrm{Cd}$ was observed. After $24 \mathrm{~h}$ and $48 \mathrm{~h}$, an evident decrease of yellow fluorescence occurred for the Cd-concentrations (Figure 4 and Table S2). When all exposure times are considered together, no significant statistical differences are found, however when only $6 \mathrm{~h}$ and $12 \mathrm{~h}$ are counted, 1 ppm and $10 \mathrm{ppm}$ are significantly different $(p<0.05)$ from the control. 


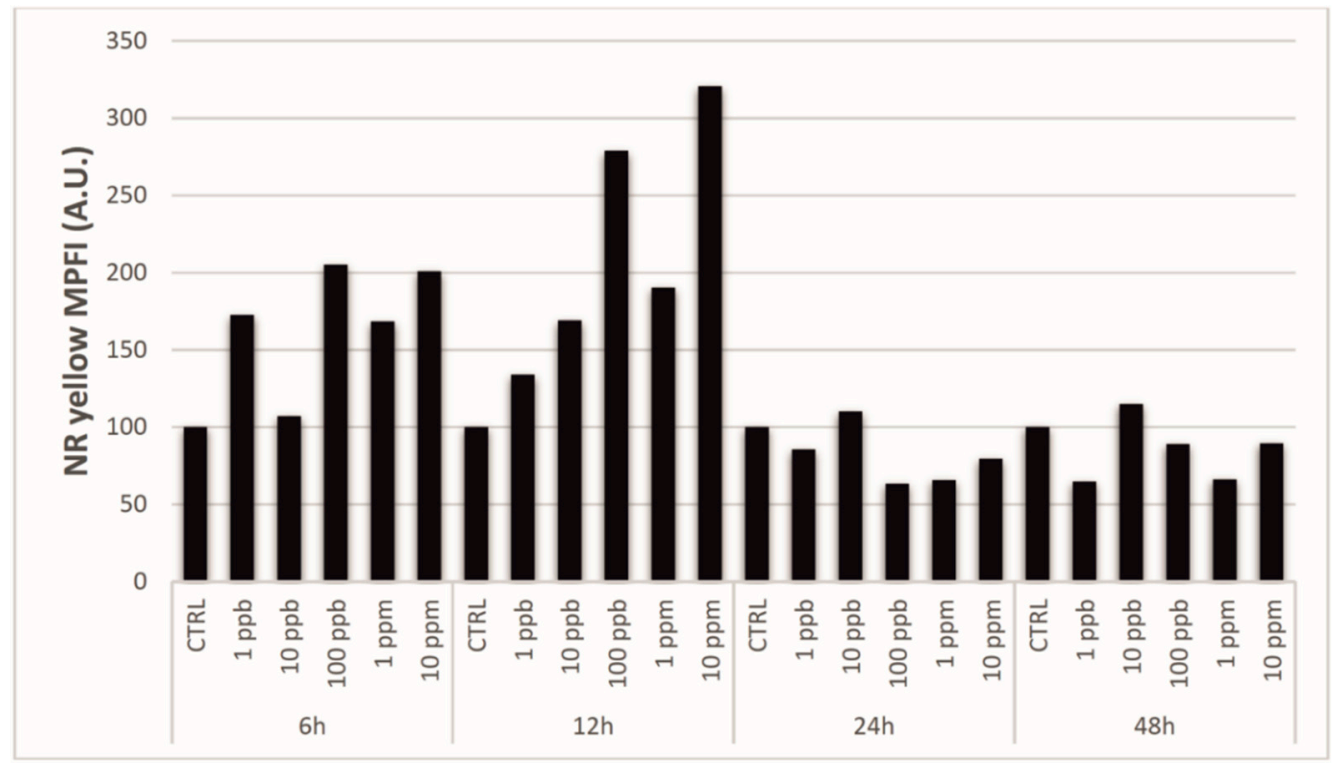

Figure 4. Histogram of yellow mean fluorescence intensity (MFI) expressed in arbitrary units (A.U.) for the treatments (control and five Cd-concentrations) and over time (6 h, $12 \mathrm{~h}, 24 \mathrm{~h}$ and $48 \mathrm{~h}$ ).

\section{Discussion}

\subsection{Effects of $\mathrm{Cd}$ on Benthic Foraminifera}

Marine and transitional marine ecosystems are affected by the discharges of different pollutants, among which, heavy metals are considered to be one of the most dangerous [1,6]. In fact, because of their toxicity, bioaccumulation, biomagnification and non-biodegradable properties, heavy metals can affect all kinds of organisms moving up through the food web [17]. Among heavy metals, cadmium is classified as particularly toxic for marine environments, as it has been reported to cause the disruption of the cytoskeleton and alterations in the phagocytic activity of animal cells [14-16]. In the context of growing heavy metal pollution, the understanding of its effect on biota is particularly important and is commonly evaluated through field-studies. Bioassay, a method to assess the effect on biota, has significantly grown in use over the last decades. Such an approach is very effective and provides a direct method to quantify the effect of a single parameter (i.e., pollutant) at different concentrations and times [19]. This approach can be achieved by culture (exposure of a single species to a single pollutant) or mesocosm (e.g., exposure of sediments and the entire community living therein to a single pollutant) experiments [19].

In this study, we evaluate the effect of $\mathrm{Cd}$ on the benthic foraminifer $A$. cf. parkinsoniana through a culture experiment. A similar approach has already been applied to other benthic foraminiferal species and pollutants (e.g., [21-24]). More specifically, several investigations have been performed to unravel the specific response of benthic foraminifera to $\mathrm{Cd}$ exposure $[4,24,35]$ that resulted in negative effects on benthic foraminifera. Similarly, our findings provide evidence of the deleterious effect of $\mathrm{Cd}$ on $A$. cf. parkinsoniana by altering the pseudopodial activity and the polarity of the lipid content. Specifically, we observe that after $12 \mathrm{~h}$ exposure at high concentrations, namely $100 \mathrm{ppb}, 1 \mathrm{ppm}$, and $10 \mathrm{ppm}$, the percentages of specimens with pseudopodial activity are dramatically reduced $(>50 \%)$. A similar pattern is also found at lower concentrations, namely $1 \mathrm{ppb}$ and $10 \mathrm{ppb}$ but at longer-time exposure $(48 \mathrm{~h})$. These findings fit well with the predicted no-effect concentration (PNEC) aqua of marine water for $\mathrm{CdCl}_{2}$ that is set at $1.14 \mu \mathrm{g} / \mathrm{L}$ (ppb) [36]. Based on this endpoint, the $24 \mathrm{~h}$ and $48 \mathrm{~h}$ median effective concentrations $\left(\mathrm{EC}_{50}\right)$ were calculated as 42.6 and $37.8 \mathrm{ppb}$, respectively. On the basis of US national recommendations for aquatic life data, the acute (criterion maximum concentration set at $1 \mathrm{~h}$ ) and chronic (criterion continuous concentration set at 4 days) concentrations for $\mathrm{Cd}$ in saltwater are 33 and $7.9 \mu \mathrm{g} / \mathrm{L}(\mathrm{ppb})$ [37]. Our observations match well with these values. A reduced pseudopodial activity 
of Ammonia tepida specimens was documented in response of Cd (cadmium chloride, up to $20 \mathrm{mg} / \mathrm{L}$ that is 20 ppm) as well as oil and two types of drilling muds after 30 days' exposure [24]. On the basis of their results, a significant reduction of pseudopodial activity, as well as that in the newly built chamber occurred at concentrations higher than $2.5 \mathrm{mg} / \mathrm{L}(2.5 \mathrm{ppm})$ and $5 \mathrm{mg} / \mathrm{L}(5 \mathrm{ppm})$, respectively. This concentration is higher than the one documented here for the decrease of pseudopodial activity, however it should be stressed that in Figure 1 of the same research paper, the concentrations ranged instead from 0.001 to $0.02 \mathrm{mg} / \mathrm{L}$ (ppm) making the threshold of $0.0025 \mathrm{mg} / \mathrm{L}$ ( $2.5 \mathrm{ppb}$ ) more comparable to our findings. The toxicity of four concentrations $(1,10,100$ and $1000 \mu \mathrm{M})$ of $\mathrm{Cd}$ (cadmium chloride hemi (pentahydrate) with a molecular weight of $228.4 \mathrm{~g} / \mathrm{mol}$ ) on Pararotalia spinigera was evaluated by [35]. By using several fluorescent probes, they documented the lack of enzymatic activity in the foraminiferal cytoplasm, the loss of functional activity of lysosomes in many benthic foraminiferal specimens and set the median lethal concentration $\left(\mathrm{LC}_{50}\right.$ : lethal concentration for killing $50 \%$ of the individual in a populations) $24 \mathrm{~h}$ at $0.56 \mu \mathrm{M}$, which equals $128 \mathrm{ppb}$. This concentration matches well with the one found in the present experiment where we observed a significant reduction of pseudopodial activity (>50\%) at concentrations of $100 \mathrm{ppb}$ after $12 \mathrm{~h}$ and $24 \mathrm{~h}$ exposure. A long-lasting experiment (21 days) was carried out with P. nipponica exposed to gradual increase of Cd [4]. This experiment documented the detrimental effect of $\mathrm{Cd}$ as revealed by a marked reduction of growth and the development of morphological abnormalities (50\%) at concentrations over $2 \mu \mathrm{g} / \mathrm{L}(\mathrm{ppb})$. Specimens were found to be still living at the end of the experiment at concentrations of up to $14 \mu \mathrm{g} / \mathrm{L}(\mathrm{ppb})$.

\subsection{Heavy Metals Effects on Benthic Foraminifera}

Deleterious effects on culture benthic foraminifera with similar concentrations (i.e., ppb) to the present experiment were documented for $\mathrm{Cu}$ [22] and $\mathrm{Hg}$ [21,23]. Two species of Ammonia (A. tepida and $A$. beccarii) were exposed to different concentrations of $\mathrm{Cu}$ (up to $500 \mu \mathrm{g} / \mathrm{L}$, that is ppb) from four months to one year. These species were found to be sensitive at low concentrations but survived up to high concentrations (threshold value $<10 \mu \mathrm{g} / \mathrm{L}$ with a lethal value $>200 \mu \mathrm{g} / \mathrm{L}$ ) [22]. The same authors documented both morphological (i.e., deformed tests) and ultrastructural (i.e., thickening of the organic lining, increased number of large lipidic vesicles and of residual bodies) changes. A decrease was documented in the growth rate and the occurrence of abnormal chambers in Rosalina leei exposed to $\mathrm{Hg}$ [21]. Specimens were still living at the highest tested concentration $260 \mathrm{ng} / \mathrm{l}$ (ppt) though there was no growth. In a similar culture experiment [23], documented that all specimens treated with a $\mathrm{Hg}$ concentration of $300 \mathrm{ng} / \mathrm{L}$ (ppt) died within 20 days. Indeed, an $\mathrm{EC}_{50}$ of $\mathrm{Zn}$ for Amphistegina lessonii, a symbiont-bearing foraminifer, was set at 100.7 and $38.2 \mu \mathrm{g} / \mathrm{L} \mathrm{(ppb)} \mathrm{for} \mathrm{the} 24 \mathrm{~h}$ and $48 \mathrm{~h}$, respectively [38]. Conversely, much higher concentrations (up to $100 \mathrm{mg} / \mathrm{L}$, that is ppm) were used to test the response of the miliolid species Pseudotriloculina rotunda to $\mathrm{Zn}$ [39]. This species showed high tolerance to $\mathrm{Zn}$ as over $60 \%$ of specimens were found to be still living at $10 \mathrm{mg} / \mathrm{L}$ (ppm) concentration.

Following the authors of [17], among heavy metals, $\mathrm{Hg}, \mathrm{Pb}$, and $\mathrm{Cd}$ are to be considered as the greatest concern. Accordingly, a laboratory toxicity test on ciliated protozoa revealed a cytotoxicity sequence of $\mathrm{Cd}>\mathrm{Cu} \gg \mathrm{Zn}$ with $\mathrm{Zn}$ found to be remarkably less toxic than $\mathrm{Cd}$ or $\mathrm{Cu}$ [40]. This overall trend is also supported by $[3,41,42]$. More specifically, LC $_{50}$ were between one and two orders of difference between $\mathrm{Cd}$ and $\mathrm{Zn}$. This difference might explain the differential tested concentrations between $\mathrm{Cd}$ and $\mathrm{Hg}$ with $\mathrm{Zn}$. Several $\mathrm{Cd}$ acute toxicity tests were performed on protozoan and revealed $24 \mathrm{~h} \mathrm{LC} 50$ values from 0.07 to $0.89 \mathrm{mg} / \mathrm{L} \mathrm{[43],} 0.195 \mathrm{mg} / \mathrm{L} \mathrm{[3],0.197} \mathrm{mg/L} \mathrm{[44].} \mathrm{Although} \mathrm{these} \mathrm{values} \mathrm{are}$ perfectly in line with our evidence of pseudopodial activity reduction, the occurrence of pseudopodial activity only provides evidence of the viability of benthic foraminiferal specimens, whereas its absence could not be used to assess the mortality of them and a direct comparison cannot be done, as clearly pointed out by [24].

Heavy metals are known to induce assemblages' (e.g., $[19,45,46])$ as well as physiological alteration and ultrastructure changes in benthic foraminifera (e.g., [22,26,45]). At ultrastructural level, these changes include the thickening of the organic lining, mitochondrial degeneration, proliferation of 
degradation vacuoles, lysosomes, residual bodies and the increased production of neutral lipids and of reactive oxygen species (i.e., $[20,28]$ ). Nile Red is a probe widely used to distinguish neutral from polar lipids. Our findings evidence an increasing yellow fluorescence in NR-labeled specimens, that are $\mathrm{Cd}$-concentration-dependent, at $6 \mathrm{~h}$ and $12 \mathrm{~h}$ exposure. These variations are associated with change in the accumulation of neutral lipids in the form of lipid droplets (LD). The enhanced occurrence of LD has also been documented in A. parkinsoniana treated with $\mathrm{Hg}$ [26] as well as in other terrestrial and marine organisms exposed to pollutants (e.g., [47]). The proliferation of LD in response to contaminants has been put forward as a mechanism to sequester toxicants in order to protect the cell $[48,49]$. An evident decrease of yellow fluorescence occurred for all Cd-concentrations even at very low ones after $24 \mathrm{~h}$. This pattern can be tentatively ascribed to the progressive loss of viability of specimens.

\section{Conclusions}

The present investigation documents the acute effect of $\mathrm{Cd}$ on the benthic foraminiferal species A. cf. parkinsoniana. On the basis of a $48 \mathrm{~h}$ time course experiment, we documented a progressive reduction in the pseudopodial activity and an increased accumulation of neutral lipids in the form of LD. These physiological and ultrastructural changes occurred at $>10-100 \mathrm{ppb}$ revealing the potential threat of Cd even at very low concentrations. These concentrations match well with the United States Environmental Protection Agency recommendation of ambient water quality criteria for the protection of aquatic life. Further studies are required to precisely define the lethal concentrations at both shortand long-term exposure to better validate field study observations and to test the water and sediment quality guidelines and thresholds.

Supplementary Materials: The following are available online at http://www.mdpi.com/2073-4441/12/4/1018/s1, Table S1: Time, concentration, number of specimens at the beginning of the experiment, living specimens with pseudopodial activity (number and percentages) at the end of the experiment, Table S2: Time, concentration, mean and standard error of NR mean fluorescence intensity (MFI).

Author Contributions: Conceptualization, F.F., E.A.-E.; methodology, M.T.L.R., E.C., B.C., C.B.; software, E.C.; formal analysis, M.T.L.R., E.C., F.F.; investigation, M.T.L.R., E.C.; resources, F.F., S.P.; writing-original draft preparation, F.F., M.T.R.L., M.V.A.M.; supervision, F.F. All authors have read and agreed to the published version of the manuscript.

Funding: This research was funded by the Kuwait Institute for Scientific Research, grant number EM084K. The APC was funded by the Kuwait Institute for Scientific Research.

Acknowledgments: The authors are very grateful to Kuwait Institute for Scientific Research for the research support. The authors are also very grateful to two anonymous reviewers for their thoughtful and valuable comments that have greatly improved the paper.

Conflicts of Interest: The authors declare no conflict of interest.

\section{References}

1. Borja, A.; Elliott, M.; Andersen, J.H.; Cardoso, A.C.; Carstensen, J.; Ferreira, J.; Heiskanen, A.-S.; Marques, J.C.; Neto, J.; Teixeira, H.; et al. Good Environmental Status of marine ecosystems: What is it and how do we know when we have attained it? Mar. Pollut. Bull. 2013, 76, 16-27. [CrossRef] [PubMed]

2. Foster, W.J.; Armynot Du Châtelet, E.; Rogerson, M. Testing benthic foraminiferal distributions as a contemporary quantitative approach to biomonitoring estuarine heavy metal pollution. Mar. Pollut. Bull. 2012, 64, 1039-1048. [CrossRef] [PubMed]

3. Gallego, A.; Martín-González, A.; Ortega, R.; Gutierrez, J.C. Flow cytometry assessment of cytotoxicity and reactive oxygen species generation by single and binary mixtures of cadmium, zinc and copper on populations of the ciliated protozoan Tetrahymena thermophila. Chemosphere 2007, 68, 647-661. [CrossRef] [PubMed]

4. Linshy, V.N.; Saraswat, R.; Kurtarkar, S.R.; Nigam, R. Experiment to decipher the effect of heavy metal cadmium on coastal benthic foraminifera Pararotalia nipponica (Asano). J. Paleontolog. Soc. Ind. 2013, 58, 205-211. 
5. Li, T.; Xiang, R.; Li, T. Influence of trace metals in recent benthic foraminifera distribution in the Pearl River Estuary. Mar. Micropaleontol. 2014, 108, 13-27. [CrossRef]

6. Stankovic, S.; Stankovic, A.R. Bioindicators of toxic metals. In Green Materials for Energy, Products and Depollution; Lichtfouse, E., Schwarzbauer, J., Robert, D., Eds.; Springer Science+Business Media: Dordrecht, The Netherlands, 2013; pp. 151-217.

7. Lesser, M.P. Oxidative stress in marine environments: Biochemistry and physiological ecology. Annu. Rev. Physiol. 2006, 68, 253-278. [CrossRef] [PubMed]

8. Eisler, R. Cadmium hazards to fish, wildlife, and invertebrates: A synoptic review. US Fish Wildl. Serv. Biol. Rep. 1985, 85, 46.

9. Eisler, R.; Zaroogian, G.E.; Hennekey, R.J. Cadmium Uptake by Marine Organisms. J. Fish. Res. Board Can. 1972, 29, 1367-1369. [CrossRef]

10. Šmirjákova, S.; Ondrašovičová, O.; Kašková, A.; Laktičová, K. The effect of cadmium and lead pollution on human and animal health. Folia Vet. 2005, 49, 31-32.

11. Ognjanović, B.I.; Marković, S.D.; Pavlović, S.Z.; Žikić, R.V.; Štajn, A.Š.; Saicić, Z.S. Effect of chronic cadmium exposure on antioxidant defense system in some tissues of rats: Protective effect of selenium. Physiol. Res. 2007, 57, 403-411.

12. Nordberg, G.F. Health hazards of environmental cadmium pollution. Ambio 1974, 3, 55-66.

13. Satarug, S.; Baker, J.R.; Urbenjapol, S.; Hasweel-Elkins, M.; Reilly, P.E.B.; Williams, D.J.; Moore, M.R. A global perspective on cadmium pollution and toxicity in non-ocupationally exposed population. Toxicol. Lett. 2003, 137, 65-83. [CrossRef]

14. Bertin, G.; Averbeck, D. Cadmium: Cellular effects, modifications of biomolecules, modulation of DNA repair and genotoxic consequences (a review). Biochimie 2006, 88, 1549-1559. [CrossRef] [PubMed]

15. Olabarrieta, I.; L'Azou, B.; Yuric, S.; Cambar, J.; Cajaraville, M.P. In vitro effects of cadmium on two different animal cell models. Toxicol. Vitr. 2001, 15, 511-517. [CrossRef]

16. Waisberg, M.; Joseph, P.; Hale, B.; Beyersmann, D. Molecular and cellular mechanisms of cadmium carcinogenesis. Toxicology 2003, 192, 95-117. [CrossRef]

17. Stanković, S.; Kalaba, P.; Stankovic, A.R. Biota as toxic metal indicators. Environ. Chem. Lett. 2013, $12,63-84$. [CrossRef]

18. Frontalini, F.; Coccioni, R. Benthic foraminifera as bioindicators of pollution: A review of Italian research over the last three decades. Revue de Micropaléontologie 2011, 54, 115-127. [CrossRef]

19. Frontalini, F.; Greco, M.; Di Bella, L.; Lejzerowicz, F.; Reo, E.; Caruso, A.; Cosentino, C.; Maccotta, A.; Scopelliti, G.; Nardelli, M.P.; et al. Assessing the effect of mercury pollution on cultured benthic foraminifera community using morphological and eDNA metabarcoding approaches. Mar. Pollut. Bull. 2018, 129, 512-524. [CrossRef]

20. Frontalini, F.; Nardelli, M.P.; Curzi, D.; Martín-González, A.; Sabbatini, A.; Negri, A.; Losada, M.; Gobbi, P.; Coccioni, R.; Bernhard, J. Benthic foraminiferal ultrastructural alteration induced by heavy metals. Mar. Micropaleontol. 2018, 138, 83-89. [CrossRef]

21. Saraswat, R.; Kurtarkar, S.R.; Mazumder, A.; Nigam, R. Foraminifers as indicators of marine pollution: A culture experiment with Rosalina leei. Mar. Pollut. Bull. 2004, 48, 91-96. [CrossRef]

22. Le Cadre, V.; Debenay, J.-P. Morphological and cytological responses of Ammonia (foraminifera) to copper contamination: Implication for the use of foraminifera as bioindicators of pollution. Environ. Pollut. 2006, 143, 304-317. [CrossRef] [PubMed]

23. Nigam, R.; Linshy, V.N.; Kurtarkar, S.; Saraswat, R. Effects of sudden stress due to heavy metal mercury on benthic foraminifer Rosalina leei: Laboratory culture experiment. Mar. Pollut. Bull. 2009, 59, 362-368. [CrossRef] [PubMed]

24. Denoyelle, M.; Geslin, E.; Jorissen, F.; Cazes, L.; Galgani, F. Innovative use of foraminifera in ecotoxicology: A marine chronic bioassay for testing potential toxicity of drilling muds. Ecol. Indic. 2012, 12, 17-25. [CrossRef]

25. Frontalini, F.; Curzi, D.; Giordano, F.; Bernhard, J.; Falcieri, E.; Coccioni, R. Effects of Lead Pollution on Ammonia parkinsoniana (Foraminifera): Ultrastructural and Microanalytical Approaches. Eur. J. Histochem. 2015, 59, 2460. [CrossRef] [PubMed] 
26. Frontalini, F.; Curzi, D.; Cesarini, E.; Canonico, B.; Giordano, F.M.; De Matteis, R.; Bernhard, J.M.; Pieretti, N.; $\mathrm{Gu}, \mathrm{B}$.; Eskelsen, J.; et al. Mercury-Pollution Induction of Intracellular Lipid Accumulation and Lysosomal Compartment Amplification in the Benthic Foraminifer Ammonia parkinsoniana. PLoS ONE 2016, 11, e0162401. [CrossRef] [PubMed]

27. Frontalini, F.; Losada, M.T.; Toyofuku, T.; Tyszka, J.; Goleń, J.; De Nooijer, L.; Canonico, B.; Cesarini, E.; Nagai, Y.; Bickmeyer, U.; et al. Foraminiferal Ultrastructure: A perspective From Fluorescent and Fluorogenic Probes. J. Geophys. Res. Biogeosciences 2019, 124, 2823-2850. [CrossRef]

28. Ciacci, C.; Grimmelpont, M.V.; Corsi, I.; Bergami, E.; Curzi, D.; Burini, D.; Bouchet, V.M.P.; Ambrogini, P.; Gobbi, P.; Ujiié, Y.; et al. Nanoparticle-Biological Interactions in a Marine Benthic Foraminifer. Sci. Rep. 2019, 9, 1-10. [CrossRef]

29. Al-Zamel, A.Z.; Al-Sarawi, M.A.; Khader, S.R.; Al-Rifaiy, I.A. Benthic foraminifera from polluted marine environment of Sulaibikhat Bay (Kuwait). Environ. Monit. Assess. 2008, 149, 395-409. [CrossRef]

30. Cherif, O.H.; Al-Ghadban, A.-N.; Al-Rifaiy, I.A. Distribution of Foraminifera in the Arabian Gulf. Micropaleontol. 1997, 43, 253. [CrossRef]

31. Greenspan, P.; Fowler, S.D. Spectrofluorometric studies of the lipid probe, nile red. J. Lipid Res. 1985, 26, 781-789.

32. Sackett, D.L.; Wolff, J. Nile red as a polarity-sensitive fluorescent probe of hydrophobic protein surfaces. Anal. Biochem. 1987, 167, 228-234. [CrossRef]

33. Greenspan, P.; Mayer, E.P.; Fowler, S.D. Nile red: A selective fluorescent stain for intracellular lipid droplets. J. Cell Boil. 1985, 100, 965-973. [CrossRef] [PubMed]

34. Diaz, G.; Melis, M.; Batetta, B.; Angius, F.; Falchi, A.M. Hydrophobic characterization of intracellular lipids in situ by Nile Red red/yellow emission ratio. Micron 2008, 39, 819-824. [CrossRef] [PubMed]

35. Bresler, V.; Yanko, v. Acute toxicity of heavy metals for benthic epiphytic foraminifera Pararotalia spinigera (Le Calvez) and influence of seaweed-derived doc. Environ. Toxicol. Chem. 1995, 14, 1687. [CrossRef]

36. European Chemicals Agency. Available online: https://echa.europa.eu/registration-dossier/-/registereddossier/14430/6/1 (accessed on 25 March 2020).

37. Acquatic Life Ambient Water Quality Criteria Cadmium; EPA-820-R-16-002; United States Environmental Protection Agency, 2016. Available online: https:/www.epa.gov/sites/production/files/2016-03/documents/ cadmium-final-report-2016.pdf (accessed on 15 March 2020).

38. Prazeres, M.D.F.; Martins, S.E.; Bianchini, A. Biomarkers response to zinc exposure in the symbiont-bearing foraminifer Amphistegina lessonii (Amphisteginidae, Foraminifera). J. Exp. Mar. Boil. Ecol. 2011, 407, 116-121. [CrossRef]

39. Nardelli, M.P.; Sabbatini, A.; Negri, A. Experimental chronic exposure of the foraminifer Pseudotriloculina rotunda to zinc. Acta Protozool. 2013, 52, 193-202.

40. Díaz, S.; Martín-González, A.; Gutiérrez, J.C. Evaluation of heavy metal acute toxicity and bioaccumulation in soil ciliated protozoa. Environ. Int. 2006, 32, 711-717. [CrossRef] [PubMed]

41. Madoni, P.; Davoli, D.; Gorbi, G.; Vescovi, L. Toxic effect of heavy metals on the activated sludge protozoan community. Water Res. 1996, 30, 135-141. [CrossRef]

42. Martín-González, A.; Díaz, S.; Borniquel, S.; Gallego, A.; Gutiérrez, J.C. Cytotoxicity and bioaccumulation of heavy metals by ciliated protozoa isolated from urban wastewater treatment plants. Res. Microbiol. 2006, 157, 108-118. [CrossRef]

43. Madoni, P.; Romeo, M.G. Acute toxicity of heavy metals towards freshwater ciliated protists. Environ. Pollut. 2006, 141, 1-7. [CrossRef]

44. Nalecz-Jawecki, G.; Sawicki, J. Toxicity of inorganic compound in Spirotox test-A miniaturised version of the Spirostomum ambiguum test. Arch. Environ. Cont. Tox. 1998, 34, 1-5. [CrossRef] [PubMed]

45. Morvan, J.; Le Cadre, V.; Jorissen, F.; Debenay, J.-P. Foraminifera as potential bio-indicators of the "Erika" oil spill in the Bay of Bourgneuf: Field and experimental studies. Aquat. Living Resour. 2004, 17, 317-322. [CrossRef]

46. Frontalini, F.; Semprucci, F.; Di Bella, L.; Caruso, A.; Cosentino, C.; Maccotta, A.; Scopelliti, G.; Sbrocca, C.; Bucci, C.; Balsamo, M.; et al. The response of cultured meiofaunal and benthic foraminiferal communities to lead contamination: Results from mesocosm experiments. Environ. Toxicol. Chem. 2018, 37, 2439-2447. [CrossRef] [PubMed] 
47. Artal, M.; Holtz, R.D.; Kummrow, F.; Alves, O.L.; Umbuzeiro, G. The role of silver and vanadium release in the toxicity of silver vanadate nanowires toward Daphnia similis. Environ. Toxicol. Chem. 2013, 32, 908-912. [CrossRef]

48. Murphy, G.; Rouse, R.L.; Polk, W.W.; Henk, W.G.; Barker, S.A.; Boudreaux, M.J.; Floyd, E.; Penn, A.L. Combustion-Derived Hydrocarbons Localize to Lipid Droplets in Respiratory Cells. Am. J. Respir. Cell Mol. Boil. 2008, 38, 532-540. [CrossRef]

49. Rowan-Carroll, A.; Halappanavar, S.; Williams, A.; Somers, C.M.; Yauk, C. Mice exposed in situ to urban air pollution exhibit pulmonary alterations in gene expression in the lipid droplet synthesis pathways. Environ. Mol. Mutagen. 2013, 54, 240-249. [CrossRef]

(C) 2020 by the authors. Licensee MDPI, Basel, Switzerland. This article is an open access article distributed under the terms and conditions of the Creative Commons Attribution (CC BY) license (http://creativecommons.org/licenses/by/4.0/). 